\title{
A comparison of vacation ownership amenities with hotel and resort hotel amenities
}

Received (in revised form): 19 February 2008

\author{
Betsy Bender Stringam \\ is an assistant professor in the School of Hotel, Restaurant and Tourism Management for \\ the New Mexico State University. Dr Bender Stringam teaches courses primarily in Hotel and \\ Resort Management, Timeshare and Vacation Ownership Management and International Hotel \\ Management. Dr Bender Stringam serves on the American Resort and Development Association \\ International Foundation Research Committee.
}

\begin{abstract}
This study evaluated resort amenities of the timeshare and vacation ownership resorts in North and South Carolina and compared the amenities with the amenities of hotels throughout the United States (US), resort hotels in the US and resort hotels in the South Atlantic region of the US The results of this study assist timeshare and vacation ownership resort management to compare their amenity offerings to hotels, provide resort operators and developers a closer look at amenities of existing vacation ownership resorts and hotels, and assist suppliers in providing amenities to and servicing existing amenities for resorts.
\end{abstract}

\section{Keywords:}

amenity, timeshare, vacation ownership, hotel, recreation, entertainment

Journal of Retail and Leisure Property (2008) 7, 186-203.

doi:10.1057/rlp.2008.10

Betsy Bender Stringam School of Hotel, Restaurant \& Tourism Management MSC 3 HRTM Po Box 30003 Las Cruces, NM 88011, USA

Tel: +15756467424

Fax: +15056468100

E-mail: betsys@nmsu.edu

\section{INTRODUCTION}

Amenities define a hotel or resort. The selection or offering of amenities at a resort is a competitive tool, helping properties to differentiate themselves against their competition (Kandampully et al., 2001).

Vallen and Vallen (2005) define amenities as 'any extra product or service found in the hotel: a swimming pool, concierge desk, health spa, and so on'.

The increase of expected amenities was coined 'amenity creep' in the late 1970s and early 1980s (Anon, 1989; Vallen and Vallen, 2005). During this time hotels and resorts tried to gain market share from their competitors by increasing amenities in the guest rooms (Bernstein, 1999). Hotels and resorts began to equate luxury with the volume of amenities or services. But the added amenities often were not highly valued or 
perceived as luxurious by their target markets. In addition, competitors often subsequently matched the amenity offerings and consumers became conditioned to expect the amenities as part and parcel of the hotel or resort accommodation. Hotels and resorts began to offer fitness centres, in-room entertainment, minibars, hairdryers, coffeemakers and ironing boards (Cornell Hotel \& Restaurant Administration Quarterly, 1989; Gilmore and Pine, 2002). Full service spas and the offering of spa services at a hotel or resort were once reserved for luxury properties. Travellers now expect spa services at mid-tier hotels and resorts (Gilmore and Pine, 2002; Foster and Mandelbaum, 2005).

The amenity creep became even more aggressive with the advent of The Heavenly Bed, by Starwood (Withiam, 1999). Since the advent of Starwoods' upgraded bedding packages, hotels and resorts became caught in the amenity creep to upgrade their mattresses, sheets, comforters, duvets, pillows and other linens. Throughout the past five years, lodging industry executives have repeatedly voiced concern over the amenity creep (Anon, 2005; Higley, 2006; Rusnak, 2006).

The amenity creep in consumer electronics and entertainment has taken a different path. Initially, consumers stayed in a hotel to experience a level of luxury they did not have at home. With the recent deluge of upgraded electronics and entertainment amenities in the home market, however, many hotels and resorts find that their offerings are less than the conveniences and luxuries enjoyed at home. As such, consumers are beginning to demand that hotels and resorts provide these upgraded amenities to their guests (Higley, 2006).

Increasing the number of amenities does not necessarily equate with increased profits (Enz et al., 1999). Additional resort amenities come at a cost to the resort and the owners. Resorts that offer an array of amenities and services to attract a large number of customer segments are likely to see an increase in the resort property's support costs in addition to the added cost of the amenity. Costs may escalate because the complexity of operations increases as the availability of products and services expand. Research has shown that hotels and resorts that are able to identify welldefined owner-customer segments, and therein maintain a narrower offering of amenities, tend to be more profitable than those offering a vast array of amenities (Hennessey, 1998; Enz et al., 1999). Profitability or desirability of a resort increases only when added amenities are valued and used by consumers. The challenge becomes in defining the amenities most beneficial to a resort.

The concept of amenity creep is not new, nor unique to hotels and resorts. Extending the business concept just a little to gain a larger share of the available customer pie is a common strategy (Dube and Renighan, 1999b). Simply copying the best practices of competitors, however, can lead to chaos and organisational failure (Hodgetts, 1999).

Vacation ownership resorts face unique challenges in the provision of resort amenities. Desirability of a resort or an interval depends on many factors. One of those factors is the relative stability of annual maintenance fees paid by owners (Rezak, 2002). One of the key responsibilities of vacation ownership resort managers is to keep annual maintenance fees low (American Resort Development Association, 2005). Amenities and 
their associated costs have a direct affect on the annual maintenance fees paid by resort interval owners. Maintenance fees are paid annually by the resort interval owners and are comprised of the annual resort operating budget and reserve accounts. These annual maintenance fees are in addition to the purchase cost of the interval or vacation ownership unit.

Vacation ownership is one of the fastest growing lodging sectors (Upchurch and Gruber, 2002). The vacation ownership industry has more than 6.7 million owners in more than 100 countries, worldwide (Global Alliance, 2002). In the United States, nearly 538,000 vacation ownership units were sold in the year 2006, with sales over \$10.0bn. (Ernst and Young, 2007). The timeshare and vacation ownership industry is the fastest growing segment of Australia's tourism industry with sales of $\$ 173 \mathrm{~m}$ in 2005 (ATHOC, 2006). In Mexico, the timeshare and vacation ownership industry comprises just over 35 per cent of the total lodging (hotel and resort) supply (AMDETUR, 2006).

This study evaluated resort amenities of the timeshare and vacation ownership resorts in North and South Carolina and compared resort amenities with the amenities of hotels throughout the United States (US), resort hotels in the US and resort hotels in the South Atlantic region of the US. The results of this study assist timeshare and vacation ownership resort management in comparing their amenity offerings to hotels, provide resort operators and developers a closer look at amenities of existing vacation resorts and hotels, and assist suppliers in providing amenities to and servicing existing amenities for resorts.

\section{LITERATURE REVIEW}

Research has examined various consumer markets and their preferences for hotel amenities. Several studies have examined business travellers to ascertain amenity preferences and importance of particular guestroom amenities (Griffin et al., 1996; Dolnicar, 2002). Bernstein (1999) posits that guests expect higher levels of luxury in their accommodations and amenities when they travel for leisure or vacation.

Whelihan and Chon (1991) discussed the changing resort hotel market. Among the consumer demands were more family friendly activities and expanded children's programmes. Another key finding of this study was that nearly all of the resort hotels in the study offered children's programmes. Gaines et al. (2004) also found the offering of children's programmes to be a growing trend in the resort hotels market. Researchers have studied preferences in hotel amenities in specific markets. Ananth et al. (1992) investigated the differences in hotel amenities preferred by the senior market segment, finding that seniors were looking for extra blankets, and grab-bars or supports in bathroom. Mann (1993) examined the difference in amenity expectations of the affluent. Heung (2000) found that while Chinese travellers to Hong Kong were generally satisfied with in-room and personal care amenities, they were not satisfied with the recreational offerings of the hotels and resorts in Hong Kong. Beldona and Cobanoglu (2007) examined consumer preferences in guestroom technologies. They found that in-room electronics such as flat screen televisions and internet access to be 
important. One of the studies most related to this study is the finding of Skogland and Siguaw (2004) which posits that chief factors that engaged guests' loyalty were hotel design and amenities.

Studies on the amenities in timeshare or vacation ownership resorts are rare. Lawton et al. (1998) determined that, the extent and quality of onsite and nearby recreational facilities, recreational activities for children and entertainment contributed to the satisfaction of Australian consumers. Other factors such as the size of the unit and kitchen facilities, however, were found to be more important. Lazar and Hobson (2002) discussed the differences in amenities between traditional timeshare product and the fractional.

The majority of the research on the timeshare and vacation ownership industry has primarily focused on consumer behaviour and the sales process (Lawton et al., 1998; Crotts and Ragatz, 2002; Rezak, 2002; Crotts et al., 2005; McCain et al., 2005; Kaufman et al., 2006; Kaufman and Upchurch, 2007; Sparks et al., 2007). Research has examined specific consumer markets and preferences in timeshare product (Hobson, 2002; Kaufman et al., 2006; Upchurch et al., 2006; Kaufman and Upchurch, 2007). While the focus of these studies was on product positioning (points, exchange options, brand affiliation), some of their findings shed light on factors that may affect the offerings of resort amenities. One study found that older vacation ownership owners utilised services at their home resort more often than younger owners (Kaufman et al., 2006). Another study found that the factors of reservation counsellor quality, resort location, resort size and availability of accommodations for preferred vacation dates affected owner satisfaction (Upchurch and Rompf, 2006). Researchers have also examined niche markets and resorts catering to these markets. They found the concept of niche offerings tailored to specific markets to be highly successful (Upchurch et al., 2006).

Other studies in vacation ownership have examined the role of the board of directors in resort management (Singh and Horwitz, 2006), the evolution of the interval product from fixed weeks to floating points (Upchurch, 2002) and employee training (Hicks and Walker, 2006). Researchers have studied various geographic markets for the vacation ownership industry (Lawton et al., 1998; Liu et al., 2001; Ladki et al., 2002; Hahm et al., 2007).

The American Hotel and Lodging Association (AH\&LA) conducts a study each year on the amenities in hotels. To date, however, there has been little research on amenities of vacation ownership and timeshare resorts; and no comparisons between hotels, resorts and timeshare and vacation ownership resorts. This research study will begin to fill that gap. The results of this study will assist resort developers, management and researchers in understanding and comparing amenities within and between timeshare and vacation ownership resorts, hotels and resort hotels.

\section{METHODOLOGY AND RESPONSE RATE}

The Carolinas comprise the fourth largest concentration of vacation ownership properties in the world. Only Florida, Mexico and Spain have 
more timeshare and vacation ownership properties (OTE, 2001; Ragatz Associates, 2004; AMDETUR, 2006; ATHOC, 2006; Bender, 2007; Canadian Resort Development Association, 2007; Ernst and Young, 2007). The Carolinas' market is diverse in geography, historical development of vacation ownership and owner demographics.

Researchers at the University of South Carolina, Central Florida University and the University of Las Vegas developed the survey instrument using the AH\&LA's 2006 lodging services, facilities and trends, websites of exchange, and timeshare and vacation ownership properties, and independent research (American Hotel and Lodging Association, 2007).

All of the resorts in North Carolina and South Carolina that were listed in the American Resort and Development Association International Foundation (AIF) database as of September 2006 were invited to participate. Respondents were encouraged to complete the enclosed survey (appendix 1) or to access the same survey via a secure website. Resorts that did not respond were telephoned. All resorts were contacted, however many resorts declined participation. Several multi-resort properties responded as a single resort, and several resorts did not yield valid contacts or addresses. This resulted in a population of 178 resorts. A total of 55 resorts participated in the study, yielding a response rate of 31 per cent. This response rate while not conclusive is well above current typical response rate for industry surveys of this type.

The results of the survey were also compared against the findings of the AH\&LA's 2006 Lodging Survey. Data from the AH\&LA study were delineated into categories. Categories used for this study were total hotels, resort hotels and South Atlantic resort hotels. The category of South Atlantic resort hotels was chosen because it included and most closely matched the composition of North and South Carolina vacation ownership resorts. Statistical calculations were conducted using Excel and SPSS. Nonresponses to categorical data were excluded from the base for calculating percentages.

\section{Testing the equality of proportions}

The Carolinas amenity study and the AH\&LA study had vastly different sample sizes. Even when the AH\&LA data were stratified into the categories of all resort hotels, and only South Atlantic resort hotels, the population and sample sizes did not equate. Statistical calculations for equality of proportions were calculated to determine if the differences in proportions could be attributed to sample size or sampling error The chisquare test for equality of proportions allows the results of two different samples to be compared for significant differences versus differences that may be attributable to expected errors in differing sample sizes (Weiers, 2002).

\section{RESULTS}

\section{Resort size}

Vacation ownership resorts that participated in the study varied in size. The overwhelming majority of the vacation ownership resorts 
(86.8 per cent) had less than 499 units, with the largest concentration (52.8 per cent) between 100 and 499 units. Very few vacation ownership resorts (13.2 per cent) were 500 units or larger. In comparison, hotels and hotel resorts averaged 104 rooms overall, with resort hotels averaging 158 rooms and resort hotels in the South Atlantic market averaging 175 rooms.

\section{Brand affiliation}

The majority (71.7 per cent) of the vacation ownership resorts responding to the survey indicated that they were independent resorts. Only 28.3 per cent were branded.

\section{General service amenities}

Almost half of the vacation ownership resorts offered owners full-service amenities. In all, 41.8 per cent of the vacation ownership resorts operated the front desk 24 hours (Table 1). A similar number of vacation ownership resorts offered a separate concierge. Hotels overall offered concierge service in significantly less properties than either vacation ownership resorts, resort hotels or resort hotels in the South Atlantic Region (Table 2). This is likely due to the number of limited service hotels in which concierge services are performed by front desk staff.

While resort hotels throughout the US and resort hotels in the South Atlantic region offered concierge service to its guests slightly more often than vacation ownership resorts, the difference was not statistically significant. In addition, many vacation ownership resorts' concierge

Table I: Timeshare and vacation ownership resort amenities

\begin{tabular}{|c|c|}
\hline Amenity & Percentage of resorts (\%) \\
\hline 24 hour Front desk & 42 \\
\hline Concierge & 42 \\
\hline Newspaper delivery to door & 20 \\
\hline Laundry and dry cleaning service & 47 \\
\hline Covered parking & 36 \\
\hline Movie theatre & 4 \\
\hline Live entertainment & 22 \\
\hline On site DVD rentals & 38 \\
\hline Game room & 47 \\
\hline Video game equipment & 18 \\
\hline Wifi common areas & 58 \\
\hline Internet access in units & 46 \\
\hline Is there a fee for use?* ${ }^{*}$ & 28 \\
\hline Owner use computer in unit & 13 \\
\hline Is there a fee for use?* & 57 \\
\hline Business resource room with Computer & 31 \\
\hline Is there a fee for use?* & 12 \\
\hline Convenience store/deli & 40 \\
\hline Poolside food and beverage service & 35 \\
\hline Alcohol service** & 68 \\
\hline Table service restaurant & 24 \\
\hline Alcohol service $* * * *$ & 77 \\
\hline Catering & 16 \\
\hline \multicolumn{2}{|c|}{ *Percentage of resorts offering amenity } \\
\hline \multicolumn{2}{|c|}{ ***Percentage of resorts with table service restaurants } \\
\hline
\end{tabular}


Table 2: Comparison of amenities between vacation ownership resorts, hotels and resort hotels

\begin{tabular}{llllllll}
\hline Amenity & $\begin{array}{l}\text { Vacation } \\
\text { ownership } \\
(\%)\end{array}$ & $\begin{array}{l}\text { All hotels } \\
(\%)\end{array}$ & $\chi^{2}$ & $\begin{array}{l}\text { All resort } \\
\text { hotels (\%) }\end{array}$ & $\chi^{2}$ & $\begin{array}{l}\text { SA resort } \\
\text { hotels (\%) }\end{array}$ & $\chi^{2}$
\end{tabular}

\begin{tabular}{|c|c|c|c|c|c|c|c|}
\hline Concierge & 42 & 24 & 9.2786 & 58 & $5.2008^{*}$ & 56 & $3.567 \mid *$ \\
\hline Newspapers delivered to door & 20 & 83 & 136.2759 & 76 & 75.7802 & 73 & 54.9507 \\
\hline Laundry and dry cleaning service & 47 & 75 & 21.6783 & 68 & 265.7983 & 68 & 8.6961 \\
\hline Staffed health spa & 31 & 11 & 20.6051 & 34 & $0.2010^{*}$ & 22 & $2.0344^{*}$ \\
\hline Gyms or exercise rooms & 55 & 75 & 11.1364 & 69 & $4.4754^{*}$ & 69 & $3.9846 *$ \\
\hline In room exercise equipment & 18 & 10 & $3.6897^{*}$ & 9 & $4.562 I^{*}$ & II & $2.0655^{*}$ \\
\hline Indoor swimming pool & 55 & 42 & $3.6759 *$ & 21 & 31.5174 & 22 & 24.5438 \\
\hline Outdoor swimming pool & 82 & 49 & 23.1452 & 87 & $1.07 \mid 4^{*}$ & 91 & $3.8725^{*}$ \\
\hline Golf course & 35 & 3 & 138.8406 & 11 & 25.0744 & 8 & 29.6190 \\
\hline Day care center & 13 & 9 & $|.024|^{*}$ & 26 & $4.5240 *$ & 22 & $2.2576 *$ \\
\hline Children's activities & 62 & 17 & 71.2821 & 39 & 10.9079 & 39 & 9.7676 \\
\hline Live entertainment & 22 & 14 & $2.7794^{*}$ & 35 & $3.7707^{*}$ & 30 & $1.4194^{*}$ \\
\hline Internet access in units & 46 & 89 & 90.0771 & 82 & 38.5687 & 81 & 29.4302 \\
\hline Fee for internet & 28 & 18 & $3.5479 *$ & 36 & $1.3997^{*}$ & 37 & $1.6034^{*}$ \\
\hline Business resource room & 31 & 59 & 17.1062 & 52 & 8.8067 & 51 & 7.2624 \\
\hline Plasma/flat television's & 9 & 12 & $0.4562 *$ & 19 & $3.3712^{*}$ & 15 & $* 1.3587$ \\
\hline DVD player in unit & 76 & 12 & 178.9304 & 23 & 69.7288 & 17 & 79.1632 \\
\hline Video game equipment & 35 & 39 & $0.3578 *$ & 41 & $0.7462^{*}$ & 43 & $1.1928^{*}$ \\
\hline Food and beverage outlet & 64 & NA & NA & 85 & $|5.649|$ & NA & NA \\
\hline Alcohol service & 77 & 43 & 24.9097 & 62 & $4.8400 *$ & 65 & $2.9542^{*}$ \\
\hline
\end{tabular}

*Significant at the 0.05 confidence level

services are actually performed by the marketing department. As such it may not be considered as concierge services, thus skewing the comparisons. A recent addition to concierge services and amenities is the advent of the electronic concierge enabling guests a self-service option. The AH\&LA reported that 13 per cent of all hotels, 14 per cent of resort hotels and 12 per cent of resort hotels in the South Atlantic region were offering guests electronic concierge service.

One in five vacation ownership resorts delivered a free newspaper to the unit doors each day, and almost half of the vacation ownership resorts provided laundry and dry cleaning service to its owners. Hotels, resort hotels and resort hotels in the South Atlantic region all offer both newspaper delivery to the door and the availability of dry cleaning and laundry services significantly more often than the vacation ownership resorts.

\section{Recreation and fitness amenities}

Vacation ownership resorts compare more favourably with hotels in the areas of recreation and fitness amenities. Swimming pools, gyms or exercise rooms, health spas, tennis courts, golf courses, fishing, playgrounds and children's activities were the primary offerings for most vacation ownership resorts regardless of location (Table 3). Ski trails and horseback riding were common recreation amenities for those vacation ownership resorts located in the mountains.

\section{Fitness-related amenities}

Almost all (91 per cent) of the vacation ownership resorts had a swimming pool (Table 3). Yet, very few vacation ownership resorts 
Table 3: Timeshare and vacation ownership resort recreation or fitness-related amenities

\begin{tabular}{lc}
\hline & Percentage of resorts (\%) \\
\hline & 31 \\
Staffed health spa & 55 \\
Gym or exercise facility & 18 \\
Exercise equipment available for in-unit use & 91 \\
Swimming pool & 55 \\
Indoor & 82 \\
Outdoor & 7 \\
Waterpark & 35 \\
Golf course & 18 \\
Mini golf & 53 \\
Tennis courts & 9 \\
Racquetball or squash courts & 47 \\
Fishing & 24 \\
Boating & 9 \\
Horseback riding & 9 \\
Ski trails & 2 \\
Ice skating & 13 \\
Day care & 62 \\
Children's activities & 47 \\
Playground & \\
\hline
\end{tabular}

(7.3 per cent) had a water park. Outdoor pools were more popular with 81.8 per cent of vacation ownership resorts having an outdoor pool and 54.5 per cent of the vacation ownership resorts having an indoor pool. Vacation ownership resorts were significantly more likely than resort hotels and resort hotels in the South Atlantic region to offer an indoor swimming pool. There was however no significant difference in the offering of indoor swimming pools between hotels throughout the US and vacation ownership resorts of the Carolinas. In contrast, vacation ownership resorts offered outdoor swimming pools significantly more often than hotels overall. There was however no significant difference in the offering of an outdoor swimming pool between vacation ownership resorts, resort hotels and resort hotels in the South Atlantic region (Table 2).

Slightly more than half ( 54.5 per cent) of the vacation ownership resorts had a state-of-the-art gym with both cardio and weight equipment. Hotels offered fitness centres more often than resort hotels or vacation ownership resorts. The results of both surveys were self-reported; therein the definition of a fitness centre may vary significantly between and within categories. It is the belief of the researcher that these findings may not accurately reflect the status of fitness centres between hotels and resorts. While resort hotels and resort hotels in the South Atlantic region were slightly more likely to offer exercise rooms than vacation ownership resorts, this difference was not statistically significant. Likewise there was no significant difference in the offerings of in-room exercise equipment between vacation ownership resorts, hotels, resort hotels or South Atlantic resort hotels.

There is an increasing demand for spas and spa services throughout the resort industry (Gilmore and Pine, 2002; McNeil and Ragins, 2005). This increased demand has resulted in more resorts and hotels offering spa amenities to their owners and guests. A staffed health spa facility was offered at 31 per cent of vacation ownership resorts. Hotels overall were 
statistically less likely to have offered a health spa to guests than vacation ownership resorts. Typically spa services are only available at full service and luxury hotels. While there were significantly less spa facilities at hotels than vacation ownership resorts, there was no significant difference between vacation ownership resorts and resort hotels, or resort hotels of the South Atlantic region. In addition to physical resources, the operation of a full service spa requires skilled employees. These factors may contribute to the findings of the study that more than a third of the spa facilities in vacation ownership resorts were outsourced (Table 6).

The Carolinas are a diverse geographic region. Golf courses are abundant throughout the Carolinas. Vacation ownership resorts were significantly more likely to provide a golf course than hotels, resort hotels or resort hotels of the South Atlantic region. Vacation ownership resorts are often located on or near a beach community on the eastern coastline, or in the mountains in the western portion of the state. Of those vacation ownership resorts located in the mountains, 43 per cent had ski trails, and one vacation ownership resort had an ice skating rink. Horseback riding was primarily in the mountains ( 29 per cent of the mountain vacation ownership resorts) with only one beach or coastal vacation ownership resort offering horseback riding.

\section{Children's amenities}

Children's activities were popular with the majority of the vacation ownership resorts providing on site children's activities. Vacation ownership resorts were significantly more likely to offer children's activities than hotels and resort hotels. In addition almost half of the vacation ownership resorts had playgrounds. Only 12.7 per cent of the vacation ownership resorts provided a day care centre for their owners' use. There was no significant difference between the provision of day care centres in vacation ownership resorts with the offering of child care services with hotels, resort hotels or resort hotels in the South Atlantic region.

\section{Computer and internet access}

Many vacation ownership resorts provided computers and computer access to owners. Vacation ownership resorts, however, lag significantly behind hotels and resorts in the offering of internet access in the unit or guest room. Only 46 per cent of vacation ownership resorts provide internet access in the unit compared to 89 per cent of hotels, 82 per cent of resort hotels and 81 per cent of resort hotels in the South Atlantic region. Vacation ownership resorts were more likely to provide WIFI access in the common areas of the resort (58.2 per cent) than in the unit (46 per cent).

About a third of the vacation ownership resorts provided a business resource room with a computer. Vacation ownership resorts were significantly less likely to provide a business resource room than hotels (59 per cent), resort hotels ( 52 per cent) and resort hotels of the South Atlantic region (51 per cent). 
Vacation ownership resorts were divided on whether or not to charge a fee to use the internet or computers. More than half of the vacation ownership resorts providing computers in the units charged for this amenity. Only about a fourth of the vacation ownership resorts with internet access in the units, however, charged a fee to the owner for inroom internet access use. While significantly less vacation ownership resorts provided in-unit internet access, the decision to charge a fee for this service compared favourably with hotels, resort hotels and resort hotels in the South Atlantic region.

\section{Entertainment and electronics}

Vacation ownership resorts provided a selection of electronics in the owner unit. More than three out of four vacation ownership resorts had a DVD player in the unit (Table 4). Hotels and resort hotels differ significantly from vacation ownership resorts in the offering of this amenity, with only 12 per cent of all hotels, 23 per cent of resort hotels and 17 per cent of South Atlantic resort hotels providing a DVD player in the guest room or unit. The AH\&LA report however indicates that when the data for hotels are segmented into quality tiers, that 53 per cent of luxury hotel properties indicated that they had DVD players in their hotel rooms.

CD players and video game equipment were also common amenities in vacation ownership resorts with 51 per cent of vacation ownership resorts providing $\mathrm{CD}$ players in the units, and 35 per cent providing video game equipment in the units. This compared favourably with hotels, resort hotels and South Atlantic resort hotels: there was no significant difference in the offering of video game equipment for use in the units or guest rooms.

Very few vacation ownership resorts had upgraded to plasma televisions, with even less planning to upgrade to plasma televisions in the next two years. There was no significant difference in the offering of flat screen or plasma televisions between vacation ownership resorts, hotels, resort hotels or resort hotels in the South Atlantic region. The AH\&LA reports that while some hotels (12 per cent overall) are introducing the flat screen televisions, they are common only in luxury hotels (51 per cent). Similarly, luxury hotels are adding high definition televisions to guest rooms. Ten per cent of all hotels, 11 per cent of resort hotels and 8 per cent of resort hotels in the South Atlantic region reported high definition televisions were in their guest rooms.

Table 4: In-unit or in-room entertainment and electronics

\begin{tabular}{lllllll}
\hline & $\begin{array}{l}\text { Plasma/flat } \\
\text { television's } \\
(\%)\end{array}$ & $\begin{array}{l}\text { High definition } \\
\text { television (\%) }\end{array}$ & $\begin{array}{l}\text { CD } \\
\text { player }\end{array}$ & $\begin{array}{l}\text { DVD player } \\
\text { in unit (\%) }\end{array}$ & $\begin{array}{l}\text { Video game } \\
\text { equipment } \\
(\%)\end{array}$ & $\begin{array}{l}\text { Cordless } \\
\text { telephones } \\
\text { in unit (\%) }\end{array}$ \\
\hline $\begin{array}{l}\text { Percent of vacation } \\
\text { ownership resorts }\end{array}$ & 9 & NA & 51 & 76 & 35 & 13 \\
$\begin{array}{l}\text { All hotels } \\
\text { All resort hotels }\end{array}$ & 12 & 10 & NA & 12 & 39 & NA \\
South east resorts & 15 & 8 & NA & 23 & 41 & NA \\
\hline
\end{tabular}


Only one fifth of the vacation ownership resorts offered live entertainment. This compared favourably with hotels and resort hotels. There was no significant difference in the offering of live entertainment with vacation ownership resorts, and hotels, resort hotels and resort hotels in the South Atlantic region.

\section{Food and beverage service}

Almost two thirds of the vacation ownership resorts provided some form of food and beverage service to their owners. Two in five vacation ownership resorts had a convenience store/deli on the property. A third of the vacation ownership resorts offered poolside food and beverage service. Less than one fourth of the vacation ownership resorts had a table service restaurant at the vacation ownership resort.

Catering was not commonly offered on vacation ownership resorts. Of those vacation ownership resorts indicating catering facilities, the catering capacity ranged from 50 seats to 400 seats, with most of the vacation ownership resorts with catering indicating a capacity between 150 and 250 seats. The provision of catering services at vacation ownership resorts appears to have been an extension of table service restaurants, as only those vacation ownership resorts with table service restaurants provided catering services.

Within the food and beverage outlets there was no significant difference in the offering of alcohol between vacation ownership resorts and resort hotels. Vacation ownership resorts were as likely to offer alcohol service in its food and beverage outlets as resort hotels, and resort hotels of the South Atlantic region. Hotels, however, were significantly less likely to offer alcohol service to its guests than vacation ownership resorts. It is possible that this difference is due to the number of limited service hotels for which the only food and beverage offerings are a breakfast buffet.

Several vacation ownership resorts outsourced or contracted the management of a food and beverage outlet to another entity. More than 50 per cent of the table service restaurants at vacation ownership resorts were outsourced. Convenience store/deli food and beverage service, and poolside food and beverage service were not as commonly outsourced with only about one in six managed by another entity. Only one vacation ownership resort indicated that their catering was outsourced.

Resort hotels were significantly more likely to offer food and beverage service than vacation ownership resorts: 85 per cent of resort hotels had at least one food and beverage outlet. The average number of food and beverage outlets for all hotels was one outlet, while resort hotels and resort hotels in the South Atlantic region both reported an average number of two food and beverage outlets.

Approximately one in four resort hotels outsourced at least one food and beverage outlet. The average number of food and beverage outlets outsourced by all hotels and all resort hotels was less than one per property, with the South Atlantic region averaging one food and beverage outlet per property outsourced or managed by a third party. While these numbers do not allow for direct comparison, it appears that outsourcing 
Table 5: Planned upgrades or improvements to timeshare and vacation ownership resorts

\begin{tabular}{ll}
\hline Upgrade & Percentage of resorts (\%) \\
\hline Plasma television's & 6 \\
Convenience store/deli & 4 \\
Poolside food and beverage & 2 \\
Table service restaurant & 0 \\
Catering & 0 \\
Better quality linens & 29 \\
Better quality pillows & 20 \\
More pillows & 18 \\
Better quality comforters & 18 \\
Better quality mattresses & 33 \\
\hline
\end{tabular}

of food and beverage outlets between hotels and vacation ownership resorts is similar.

\section{Planned upgrades or improvements}

Planned upgrades or improvements to vacation ownership resorts focused on upgrades to the bed (Table 5). Almost a third of the respondents planned to upgrade their mattresses and linens in the next two years. Overall respondents indicated very few upgrades to food and beverage facilities. Only a few vacation ownership resorts were planning to upgrade to plasma televisions within the next two years.

Recent years have seen guests and owners demanding better bedding. This increased demand has led to upgrades in linens, duvets, pillows and mattresses for the hotel and resort industry. The AH\&LA reported that more than two thirds of hotels and resort hotels upgraded their bedding package in the last year. Sixty-nine per cent of all hotels upgraded bedding, 66 per cent of all resort hotels and 68 per cent of resort hotels in the South Atlantic region upgraded their bedding in the last year. While these findings are not comparable statistically, it appears that vacation ownership resorts may be upgrading bedding at a slower or less frequent rate than hotels and resort hotels.

\section{Outsourcing}

Several vacation ownership resorts in the Carolinas outsourced or contracted the management of an outlet to another entity (Table 6). More than 50 per cent of the table service restaurants were outsourced. Convenience store/deli food and beverage service, and poolside food and beverage service were not as commonly outsourced with only about one in six managed by another entity. Only one resort indicated that their catering was outsourced. Hotels and resort hotels on the average do not outsource food and beverage outlets as commonly as vacation ownership resorts. The AH\&LA report indicated that only 18.7 per cent of all hotels and 26 per cent of all resort hotels outsource the management of a food and beverage outlet to a third party.

\section{DISCUSSION}

Timeshare and vacation ownership resorts in the Carolinas offer an abundance of amenities to owners. While amenity offerings vary between 
Table 6: Timeshare and vacation ownership resort amenity outsourcing or management by a third party

\begin{tabular}{ll}
\hline Amenity & $\begin{array}{l}\text { Of resorts indicating amenity, percentage } \\
\text { that are outsourced (\%) }\end{array}$ \\
\hline Health spa & 35 \\
Convenience store/deli & 18 \\
Poolside food and beverage & 16 \\
Table service restaurant & 54 \\
Catering & 11 \\
\hline
\end{tabular}

vacation ownership resorts, the most common vacation ownership resort amenities were swimming pools, exercise rooms or gyms, tennis courts and children's activities. The most commonly reported unit amenities included WIFI internet access, DVD players and CD players. Current plans for upgrades or improvements to vacation ownership resorts and units focus on the bedding. Overall, vacation ownership resorts in the Carolinas region compare favourably with hotels in the US, resort hotels in the US and resort hotels in the South Atlantic region of the US in the offering of amenities to owners and guests.

Hotels and resort hotels were more likely to offer services demanded by business travellers than vacation ownership resorts in the Carolinas. Specifically hotels, resort hotels and resort hotels in the South Atlantic region were significantly more likely to deliver newspapers to the guest room or unit door, provide internet access in the guest room/unit and to provide a business resource room for guests and owners. At first glance, these findings may be explained or excused because of the varying nature of guests in hotels and resort hotels, from owners or guests in vacation ownership resorts. While hotels and resort hotels have a mixture of leisure and business travellers, vacation ownership resort usage is almost exclusively leisure travel. Even in leisure travel, however, many guests and owners still conduct business transactions or have a need to connect to their place of business. Even those not mixing work with leisure may feel the need to stay connected to information or sources. In addition, the use of the internet and computers has pervaded the leisure habits of most Americans. Communication through email and instant messaging is common among families and friends. It is expected that vacation owners will desire increased communication amenities. Vacation ownership properties will need to examine the offerings of computer and internet access for owners on their properties.

Vacation ownership resorts in the Carolinas were more likely to provide recreation amenities than hotels overall. Staffed health spas, outdoor swimming pools, golf courses, children's activities and inunit/room DVD players were significantly more common in vacation ownership resorts than in hotels. Vacation ownership resorts in the Carolinas, however, offered only a few more amenities than resort hotels in the US, or resort hotels of South Atlantic US region. Only children's activities and the provision of in-unit/room DVD players were more likely to occur at vacation ownership resorts than resort hotels, or resort 
hotels of the South Atlantic region. Thus, the offering of amenities of vacation ownership resorts in the Carolinas compares favourably with the offering of amenities of their counterpart, resort hotels. Overall, vacation ownership resorts in the Carolinas offer similar and comparable amenities as resort hotels.

Consumers compare amenity offerings of vacation ownership resorts against other vacation ownership resorts and the commercial hotel and resort industry. Resorts that do not offer amenity packages comparable to the rest of the resort industry or the commercial hotel and resort industry may face the prospect of losing market share or competitive advantage. This study allows vacation ownership resorts to evaluate amenity trends against the marketplace, to offer a competitive amenity package, yet keep costs and annual maintenance fees low. The results of this study may also assist in planning capital replacement budgets and replacement reserves for vacation ownership resorts.

\section{LIMITATIONS OF THE STUDY AND FUTURE STUDY RECOMMENDATIONS}

This study is neither conclusive nor makes recommendations for resort or hotel amenities. Resort and hotel amenities are often dependent upon location, and are undoubtedly dependent upon the requisites of their owners and guests. Developers and operators of vacation ownership resorts should not offer an amenity as a result of the findings of this study. Rather, they should determine the needs and wants of their owner base and exchange guests, and then perform further analysis on the costs, requirement and benefits of adding the amenity. A review of best practices for hotels found that instead of 'giving the customers more, whether they asked for it or not' successful lodging operations assess all sides of a profit equation before offering a new product or service, regardless of what the competition does (Dube and Renighan, 1999a, b). Simply adding an amenity because other resorts offer the amenity may not be a profitable strategy (Hennessey, 1998; Enz et al., 1999; Rusnak, 2006).

It should also be noted, that this study only included resorts in the Carolinas. While the study results can be used for comparison and discussion, no inferences or estimates can be made from this study to a national or international resort market. It would be expected that future studies would encompass vacation ownership resorts throughout the US and/or the world. It may be highly possible that the amenity offerings in other regions of the world differ significantly from the amenity offerings of the Carolinas. In addition, the geographic regions of the two data sets used for the study did not equate exactly. While North and South Carolina were included in the South Atlantic region for the AH\&LA study, there were other states in this region included in these data. The study of amenities in vacation ownership resorts of the Carolinas only included resorts in North and South Carolina. Future studies could compare amenities between hotels and vacation ownership resorts in exact geographic regions. 


\section{References}

AMDETUR (2006). An Overview of the Economy and Tourism Sector. 2006 Study of Latin American and the Caribbean, AMDETUR, Mexico City.

American Hotel \& Lodging Association (2007). 2006 Lodging Survey, American Hotel \& Lodging Educational Foundation, Washington, DC.

American Resort Development Association (2005). The Timeshare Industry Resource Manual, American Resort Development Association, Washington, DC.

Ananth, M., DeMicco, F., Moreo, P. \& Howey, R. (1992). Marketplace lodging needs of mature travellers. Cornell Hotel \& Restaurant Administration Quarterly. 33(4), 12.

Anon. (1989). Amenities creep. Cornell Hotel \& Restaurant Administration Quarterly. 30(1), 5.

Anon. (2005). Operations, technology spark at hot 5. Lodging Hospitality. 61(5), 70-71.

ATHOC (2006). The Economic Significance of the Australian Timeshare and Holiday Ownership Industry, Australian Timeshare and Holiday Ownership Council, Ltd. Bundall, Queensland, Australia.

Beldona, S. \& Cobanoglu, C. (2007). Importance-performance analysis of guest technologies in the lodging industry. Cornell Hotel \& Restaurant Administration Quarterly. 48(3), 299-312.

Bender, B. (2007). A quick look at the international timeshare and vacation ownership market. White Papers, Alfred P. Sloan International Center for Travel and Tourism, University of South Carolina.

Bernstein, L. (1999). Luxury and the hotel brand. Cornell Hotel \& Restaurant Administration Quarterly. 40(1), 47.

Canadian Resort Development Association (2007), Retrieved 10th December 2007 from http:// www.crda.com/about_us.shtml.

Crotts, J.C., Aziz, A. \& Upchurch, R.S. (2005). Relationship between Machiavellianism and sales performance. Tourism Analysis. 10(1), 79-84.

Crotts, J.C. \& Ragatz, R.L. (2002). Recent US timeshare purchasers: Who are they, what are they buying, and how can they be reached? International Journal of Hospitality Management. 21(3), 227.

Dolnicar, S. (2002). Business travellers' hotel expectations and disappointments: A different perspective to hotel attribute importance investigation. Asia Pacific Journal of Tourism Research. 7(1), 29-35.

Dube, L. \& Renighan, L. (1999a). Strategic approaches to lodging excellence: A look at the industry's overall best-practice champions. The Cornell Hotel and Restaurant Administration Quarterly. 40(6), 16-26.

Dube, L. \& Renighan, L. (1999b). Sustaining competitive advantage. The Cornell Hotel and Restaurant Administration Quarterly. 40(6), 27-33.

Enz, C., Potter, G. \& Siguaw, J. (1999). Serving more segments, offering more products. The Cornell Hotel and Restaurant Administration Quarterly. 40(6), 54-62.

Ernst \& Young (2007). State of the Vacation Timeshare Industry: United States Study 2006 Edition, American Resort and Development Association International Foundation, Washington, DC.

Foster, A. \& Mandelbaum, R. (2005). Hotel spas, the new recreational vehicle for hotel profits. Hotel news resource. Retrieved 27th December, 2007 from http://www.hotelnewsresource.com/ article19176.html.

Gaines, B., Hubbard, S., Witte, J. \& O'Neill, M. (2004). An analysis of children's programs in the hotel and resort industry market segment. International Journal of Hospitality \& Tourism Administration. 5(4), 85-99.

Gilmore, J. \& Pine, J. (2002). Differentiating hospitality operations via experiences. The Cornell Hotel and Restaurant Administration Quarterly. 43(3), 87-96.

Global Alliance for Timeshare Excellence (2002). General facts and statistics. Retrieved 15th December, 2007 from http://www.gatexcellence.org/abouttimeshare.html.

Griffin, R., Shea, L. \& Weaver, P. (1996). How business travellers discriminate between mid-priced and luxury hotels. Journal of Hospitality and Leisure Marketing. 4(2), 63-75.

Hahm, J., Lasten, E., Upchurch, R.S. \& Peterson, R. (2007). State of the timeshare industry in Aruba - A call for research. Journal of Retail \& Leisure Property. 6(3), 221-229.

Hennessey, S. (1998). Beware amenity creep before it devours property profits. Hotel \& Motel Management. 213(6), 12.

Heung, V.C.S. (2000). Satisfaction levels of mainland Chinese travellers with Hong Kong hotel services. International Journal of Contemporary Hospitality Management. 12(5), 308.

Hicks, G.J. \& Walker, M.D. (2006). Training in the timeshare industry. Tourism \& Hospitality Research. 6(4), 296-300.

Higley, J. (2006). Guest satisfaction dependent on positive experience. Hotel \& Motel Management. 221(4), 20. 
Hobson, W. (2002). A research report on private residence clubs: A new concept for second home ownership. International Journal of Hospitality Management. 21(3), 285.

Hodgetts, R. (1999). A Conversation with Michael E. Porter: A significant extension toward operational improvement for positioning. Organizational Dynamics. 28(1), 24-33.

Kandampully, J., Mok, C. \& Sparks, B. (2001). Service Quality Management in Hospitality, Tourism, and Leisure, Haworth Press, New York.

Kaufman, T. \& Upchurch, R. (2007). Vacation ownership: Gender positioning. Journal of Retail \& Leisure Property. 6(1), 8-14.

Kaufman, T., Upchurch, R. \& Severt, D. (2006). Vacation ownership: Understanding the senior market. Journal of Retail \& Leisure Property. 5(2), 95-103.

Ladki, S., Mikdashi, S., Fahed, W. \& Abbas, H. (2002). Arab tourists and the Lebanese vacation ownership industry: A quality of life perspective. International Journal of Hospitality Management. 21(3), 257.

Lawton, L., Weaver, D. \& Faulkner, B. (1998). Customer satisfaction in the Australian timeshare industry. Journal of Travel Research. 37(1), 30.

Lazar, J. \& Hobson, W. (2002). Private residence clubs: A new concept for second home ownership. Journal of Leisure Property. 2(2), 105.

Liu, J., Pryer, M. \& Roberts, A. (2001). Timeshare opportunities in china: An evaluation of the conditions for market development. Journal of Vacation Marketing. 8(1), 88.

Mann, I. (1993). Marketing to the affluent: A look at their expectations and service standards. Cornell Hotel \& Restaurant Administration Quarterly. 34(5), 54.

McCain, S., Hu, C. \& Woods, R. (2005). Examining job-related factors perceived by salespersons in the U.S. timeshare industry: A path analysis. Journal of Travel \& Tourism Marketing. 19(1), $29-38$.

McNeil, K. \& Ragins, E. (2005). Staying in the spa marketing game. Journal of Vacation Marketing. 11(1), 31-39.

OTE (2001). The European Timeshare Industry in 2001. Organisation for Timeshare in Europe, Brussels, Belgium.

Ragatz Associates (2004). Resort Timesharing in Southern Africa 2004, Timeshare Institute of Southern Africa, Durban.

Rezak, S. (2002). Consumer research sheds light on all aspects of resort timesharing business. International Journal of Hospitality Management. 21(3), 245.

Rusnak, P. (2006). Leaders: Guests' needs pose challenges. Hotel \& Motel Management. 221(1), 4, 50.

Singh, A. \& Horwitz, R. (2006). The board of directors in timeshare governance: Ownermanagement relations in timeshare resort operations. Journal of Retail \& Leisure Property. 5(3), 185-196.

Skogland, I. \& Siguaw, J.A. (2004). Are your satisfied customers loyal? Cornell Hotel \& Restaurant Administration Quarterly. 45(3), 221-234.

Sparks, B., Butcher, K. \& Pan, G. (2007). Understanding customer-derived value in the timeshare industry. Cornell Hotel \& Restaurant Administration Quarterly. 48(1), 28-45.

Upchurch, R. (2002). Product design evolution in the vacation ownership industry: From fixed weeks to points and vacation clubs. Journal of Leisure Property. 2(3), 239.

Upchurch, R. \& Gruber, K. (2002). The evolution of a sleeping giant: Resort timesharing. International Journal of Hospitality Management. 21(3), 211.

Upchurch, R. \& Rompf, P. (2006). Postpurchase behavior: A case study into a vacation club product. Tourism Analysis. 11(1), 45-59.

Upchurch, R., Rompf, P. \& Severt, D. (2006). Segmentation and satisfaction preferences of specific looking glass cohorts' profiles: A case study of the timeshare industry. Journal of Retail \& Leisure Property. 5(3), 173-184.

Vallen, J. \& Vallen, G. (2005). Check-In, Check-Out, Pearson Prentice Hall, Upper Saddle River, New Jersey.

Weiers, R.M. (2002). Introduction to Business Statistics, Wadsworth Group/Thompson Learning, Belmont, California.

Whelihan, W. \& Chon, K. (1991). Resort-marketing trends of the 1990s. Cornell Hotel \& Restaurant Administration Quarterly. 32(2), 56.

Withiam, G. (1999). Speaking of sleep. Cornell Hotel \& Restaurant Administration Quarterly. $40(5), 8$. 


\section{Appendix}

1. Name of Resort

2. Size of resort

$\square$ under 100 rooms
$\square$ between 500 and 999
$\square$ between 1500 and 2000

3. Is the resort $\square$ independent or $\square$ branded?

$\square$ between $100-499$
$\square$ between 1000 and 1499
$\square$ over 2000

\section{Resort Amenities Does your resort provide:}

4. A staffed health spa?

a. If so, is the spa managed by an outside company?

$\square$ Yes

$\square$ Yes

$\square$ Yes

$\square$ Yes

$\square$ Yes

6. In-room exercise equipment available for guest use?

7. A day care center?

8. Free newspapers delivered to your unit's doors?

9. Laundry/dry cleaning service available at your resort?

10. 24-hour front desk service?

11. A Concierge?

12. Covered parking? a. If yes, for all units?

13. Children's activities

14. Swimming Pool,

$$
\text { a. indoor }
$$

b. outdoor

15. Waterpark

16. Tennis Courts

17. Movie theatre

18. Golf Course

19. Miniature Golf Course

20. Game Room

21. Fishing

22. Boating

23. Horseback Riding

24. Playground

25. Ski Trails

26. Ice Skating

27. Game Room

28. Racquetball or Squash Courts

29. Casino

30. Live Entertainment

$\square$ Yes

$\square$ Yes

$\square$ Yes

$\square$ Yes

$\square$ Yes

$\square$ Yes

$\square$ Yes

$\square$ Yes

Yes

- Yes

Yes

$\square$ Yes

$\square$ Yes

$\square$ Yes

$\square$ Yes

$\square$ Yes

口 Yes

$\square$ Yes

$\square$ Yes

$\square$ Yes

$\square$ Yes

$\square$ Yes

$\square$ Yes

$\square$ Yes

$\square$ Yes
Internet and Computers Does your resort provide:

31. Broadband Internet service in your units?
a. Wi-Fi,
b. Wired
c. Both?
d. Is there a fee associated with use?

32. WIFI In your common areas?

33. A guest-use computer in your unit?

a. Is there a fee associated with use?

34. A business resource room?

a. With a computer for guest use?

b. Is there a fee associated with use of the computer?

$\square$ Yes

$\square$ Yes

$\square$ Yes

$\square$ Yes

$\square$ Yes

$\square$ Yes

$\square$ Yes

$\square$ Yes

$\square$ Yes

$\square$ Yes

$\square$ Yes

\section{Other in- room electronics Does your resort provide:}

35. Cordless telephones in your units?

36. Plasma TVs in your units?

a. If no, is there a plan to upgrade to plasma TV's in the next two years?

37. CD players in your units?

38. DVD players in your units?

39. On site DVD rentals?

40. Video game equipment or capabilities in the units?

$\square$ Yes

$\square$ Yes

41. Video game equipment or capabilities available for use on the property?

$\square$ Yes

$\square$ Yes 


\section{Food \& Beverage Does your resort have:}

42. A convenience store/deli?

$\square$ Yes

$\square$ Yes

a. If yes, does it offer prepared foods (pizza, sandwiches, etc.)?

Yes

b. If yes, is it out-sourced?

c. If no, do you plan to add one in the next 24 months?

43. A poolside food and beverage facility?

a. If yes, are alcoholic beverages available?

b. If yes, is it outsourced?

c. If no, do you plan to add one in the next 24 months?

44. A table-service restaurant?

a. If yes, are alcoholic beverages available?

b. If yes, is it outsourced?

c. If no, do you plan to add one in the next 24 months?

45. Catering or banquet facilities?

a. If yes, maximum banquet-style seating occupancy?

b. If yes, is it outsourced?

c. If no, do you plan to add facilities in the next 24 months?

$\square$ Yes

$\square$ Yes

$\square$ Yes

$\square$ Yes

$\square$ Yes

$\square$ Yes

$\square$ Yes

$\square$ Yes

$\square$ Yes

$\square$ Yes

$\square$ Yes

$\square$ Yes

46. What are the top three food types your owners/guests are asking for?

Linens

47. Please describe the in-unit bath towels (if known):
a. Color
b. Typical size

c. Poundage

48. Please describe the in-unit bed sheets (if known):
a. Color
b. Thread count

49. Are you planning any of the following changes to your bedding programs within the next 24 months?
a. Adding better quality linens
b. Adding better quality pillows
$\square$ Yes
c. Adding more pillows
d. Adding better quality comforters/duvets
$\square$ Yes
e. Adding better quality mattresses
$\square$ Yes
$\square$ Yes
$\square$ Yes

\section{Miscellaneous}

50. How often do you replace your major appliances (washers, dryers, stoves, etc.)?
$\square$ Annually
$\square$ Every $2-5$ years
$\square$ Every $6-9$ years
$\square$ Every 10 years or more

51. What features would you like to see on appliances that might help your guests have a better vacation?

52. Which small appliances do you replace most frequently? (check all that apply)
$\square$ Coffee maker
$\square$ Microwave
$\square$ Iron
$\square$ Hair Dryer
$\square$ Toaster
$\square$ Blender

53. Please rate your satisfaction with your current Human Resources recruitment source. Please mark your rating on the scale: Very Dissatisfied Dissatisfied Neutral Satisfied Very Satisfied

54. What Human Resources recruitment sources are you utilizing (check all that apply)?
$\square$ Local on-line
$\square$ National on-line
$\square$ Local classified (print) ads
$\square$ Job fairs

55. Which is most effective?
$\square$ Local on-line
$\square$ National on-line
$\square$ Local classified (print) ads
$\square$ Job fairs 